\title{
OPERATIONAL AND FINANCIAL STRATEGIES FOR PEKING DUCK BREEDING START UP BUSINESS INTEGRATED WITH ECO-GREEN
}

\author{
Lie T.U.*, Syah T.Y.R., Erni N. \\ Master Program of Management, Faculty of Economy and Business, Esa Unggul University, \\ Jakarta, Indonesia \\ *E-mail: tanunlie@gmail.com \\ ORCID 0000-0002-3430-4382
}

\begin{abstract}
Duck farming needs to be innovated from traditional maintenance management systems that must be abandoned, costly modern intensive maintenance management and pollute the environment into an efficient and eco-green intensive maintenance system by applying the same system partnership pattern to its core. Integrated eco-green intensive peking duck breeding farm utilizing Azolla Microphylla and hedge leaf as feed supplement and other germplasm utilization. The Azolla Microphylla plant serves as a phytoremediation where it can recycle livestock wastewater into clean water thereby reducing excessive water exploitation and reducing the pollution of the stench. The purpose of this research is to obtain information about the financial strategy to start up the business of peking duck integrated with eco-green model. Beginning from planning activities, the company implements project management system with its Gantt Chart. The mapping of operational strategy is carried out comprehensively by always making continuous improvement (kaizen) because in the current era to be good alone is not enough, but struggle is needed to be superior (market leader) by beginning by cost leader.
\end{abstract}

\section{KEY WORDS}

Operational strategy, finance, start-up business, eco-green.

According to Central Bureau of Statistics (BPS), Banten Province as an operational area of duck breeding livestock business has a population of $11,955,243$ million people or $4.66 \%$ of the total population of Indonesia in 2015 (254.9 million people). From that number, the male population is 6.097 .184 million and the female population is 5.858 .059 million people (Central Bureau of Statistics in Banten). According to Central Bureau of Statistics projection, the population of Banten reaches 13.1 million people or $4.85 \%$ of 271.0 million people by 2020 . In fact, by 2035 , it is projected that the population of Banten will reach 16.0 million people or $5.24 \%$ of the 305.6 million people in Indonesia. With the increasing number and the rate of population growth of Banten from year to year, it surely will make Banten as a big enough potential market for the development of duck breeding business in the future.

The number of restaurants in Banten province in 2011 was 797 and continues to grow to 1,110 in 2014 . This number will certainly continue to increase along with the more conducive political climate, the better economic conditions and national economic growth target of $5.4 \%$ in 2016 . This condition will of course be good enough for Banten's economic growth. Opportunity to market duck breeding from raising duck breeding business, so it will boost the role of duck in the fulfillment of the needs and availability of meat in Indonesia, especially Banten province as an operational area of peking meat breeding business.

Duck breeding productivity can be improved through the implementation of government policies to support the development of livestock production systems and with assembly of technological innovations that are appropriate for the people's farmers. Technological innovation, in addition to livestock productivity, should also address aspects of animal health management as well as safe and lawful livestock product processing. Implementation of government policies to build strong breeders supported by universities is needed to increase the contribution of duck breeding significantly in meeting the needs of animal food. 
Duck farming needs to be innovated from traditional maintenance management systems that must be abandoned, costly modern intensive maintenance management and pollute the environment into an efficient and eco-green intensive maintenance system by applying the same system partnership pattern to its core. In duck maintenance management, there are influential factors, including the quality of seeds used, proper maintenance procedures, quality and appropriate feeding methods, appropriate research and technology, business systems and good financial analysis, experience in raising livestock enough ducks, strict biosecurity systems and marketing of livestock products.

Peking Duck Breeding Farm Integrated with Eco-Green Concept. Integrated eco-green intensive peking duck breeding farm utilizing Azolla Microphylla and hedge leaf as feed supplement and other germplasm utilization. The Azolla Microphylla plant serves as a phytoremediation where it can recycle livestock wastewater into clean water thereby reducing excessive water exploitation and reducing the pollution of the stench. The development of farms using strategic partnerships is intended to recruit traditional farmers to switch to intensive eco-green farming systems and become a strategic partner of core peking meat breeding companies with mutually beneficial cooperation in terms of increasing livestock productivity with good management, ensuring availability Day Old Duck (DOD) seedlings, Azolla Microphylla and hedge leaf feed supplements to produce organic equivalent meat products, and livestock marketing at competitive and profitable prices.

Peking duck breeding farm eco-green concept applies six steps of farm management, which are: 1) Eco-Green Housing Farm Management; 2) Breeding Management; 3) Hatchery Management; 4) Growing Management; 5) Feeding Management; 6) Azolla Microphylla pond management and hedge plant management;, 7) Butchering Ducks (Processing Management); and 8) Marketing Management.

Operational Strategy. PT Prima Duckindo has a framework in the implementation of operational strategies that must be achieved in running the duck breeding business. The operational framework is divided into two parts, namely management within the preoperational time range and within operational time. Pre-operation is an activity of the results of analyzing the Quantitative Strategic Planning Matrix (QSPM) as a tool that enables strategic strategists to evaluate alternative strategies objectively and holistically, based on internal key and external key success factors identified in chapter III. Legal permits and project management to establish livestock are pre-operative activities.

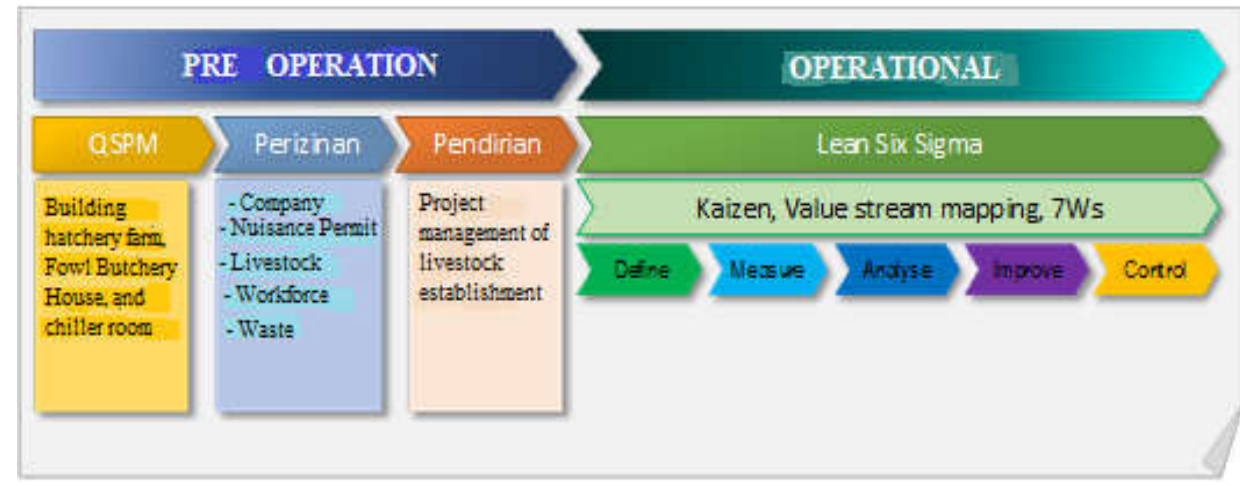

Figure 1 - PT Prima Duckindo Operational Framework

In the operational phase, PT Prima Duckindo selects Lean Six Sigma system as the chosen industrial management for livestock. The maintenance of ducks using an intensive system with the method of duck rose in a closed stable with a climate-adjusted ventilation design and regulated the temperature of the stable space to be comfortable for ducks swarm. Therefore, commercial duck meat production for PT Prima Duckindo is a special business core that requires large investment and timely management.

In accordance with Figure 1 regarding the operational framework of PT Prima Duckindo, it is seen that management performed in the pre-operative stage is the result of QSPM analysis. This analysis resulted in an analysis to establish an integrated livestock from 
start breeding ducks (breeder farm), hatching of ducks (hatchery), enlargement of ducks (grower farm), and poultry butchery house (processing farm) which constitute the operational objectives of the company. Furthermore, licenses are also a regulation that must be implemented to run the sustainability of the company's operations. Finally from this subchapter, it is project management that manages in building integrated farms.

PT Prima Duckindo to realize LSS management system hence mapping the target or operational objectives comprehensively as the spirit for Kaizen (continuous improvement). A necessity nowadays of industry and business environments are reaching the point of competition for survival and market share. Following the global economy will show that being good is not enough, therefore every organization must really strive for excellence if it wants to stay in the market. Each organization has a primary goal to look for one unit of outcome that is profit. This operational objective raises operational targets for the integrated duck meat industry of PT Prima Duckindo which embraces the system: Quality, Cost, Delivery, Safety, Moral, Productivity, which is abstracted from the mindset in the production field that is 7W's (7 types of waste $=$ Motion, waiting time, over production, processing time, defects, inspection, and transportation).

Establishing companies in Indonesia is actually not too difficult because all the existing regulations that govern it, inter-departmental coordination in the reform era and the digital era make the process and licensing procedures easier and transparent. The government continues to make efforts to simplify start-up business procedures. In addition to the number of entrepreneurs in Indonesia which is still very small compared to neighboring countries, establishing new business is considered providing added value as it opens more jobs and drives the local economy. One of the initiatives undertaken by the government is to facilitate the establishment of Limited Liability Company (PT). Stages of licensing and regulations to be implemented by PT Prima Duckindo are as follows: Licensing of Company Establishment, Licensing of Law Interruption, Licensing of Waste, Licensing of Business Livestock, and Regulations of Livestock Partnerships.

Establishing a business is one of the key phases to start and grow a business. Establishing PT (Limited Liability Company) is not confusing anymore if it intends to seek additional capital, holds a new investor, or participates in tenders held in government agencies. To establish a company with the name of the company which is PT Prima Duckindo, it needs the preparation of documents as a condition of submission, namely the lease agreement of land. The landowner includes the Land and Building Tax (PBB) of the previous year and Building Construction Permit (IMB) for the completeness of the data at the time of the notarial deed as the domicile of the company. The other data that need to be prepared to register at the Office of One Stop Services Integrated Services (BPMPTSP) include: the name option of the company (minimum 3), business field, the names of shareholders \& ID cards, the composition of shareholders, authorized capital company (minimum 51,000,000 Rupiah), paid up capital (minimum 51,000,000 Rupiah), composition of directors and commissioners, ID Cards of directors and commissioners, Tax Registration Number of directors, $3 \times 4$ photographs (2pcs). Figure 5.4 describes in detail the flow of the company's license making which is done by PT Prima Duckindo.

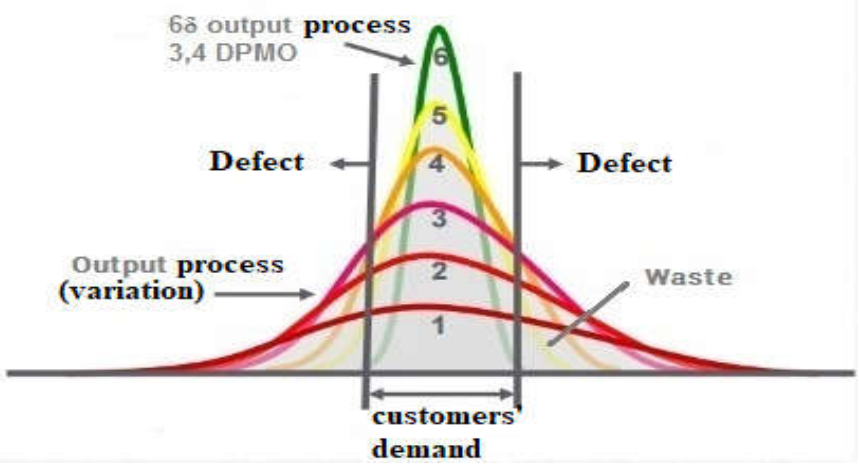

Figure 2 - Representation of Sigma and Waste on Normal Distribution 
Lean Six Sigma is a methodology of continuous improvement that incorporates the DMAIC (Define, Measure, Analyze, Improve, Control) and statistical analysis tools of Six Sigma and combine them with the tools Manufacturing lean to eliminate or reduce significantly the 8 types of waste (waste) as looses in the value stream, trying to cause the loss to zero. Lean Six Sigma is a process that aims to process $6 \sigma$ (sigma).

The six sigma process is a process in which 3.4 defects Defects per Million Opportunities (DPMO). Two important steps in Lean Six Sigma to measure variation are mean and standard deviation. One of the most important measures in Lean Six Sigma is Sigma, or standard deviation. Sigma is used as a metric to measure variations in processes. The tighter the variation, the higher the quality of the process. A process is stated to be a Six Sigma process if six standard deviations can fit between each of the process mean sides and customer specifications. This is equivalent to $\mathrm{Cpk}=2.0$.

Lean's main principle is the down-line improvement through waste eradication in the value stream, waste as identified by the customer. Value-added activities is an activity that the customer is willing to pay for all other activities, which are classified as non-value-added activities are classified as waste. What customers want to pay for a work is a plus on a product, service, or unit. Activities that turn raw goods into finished goods. Activities are not value-added (non-value added) consists of 8 types of waste which can be shortened to DOWNTIME, namely: Defects, Over-production, Waiting, Non-utilized Resources/Talent, Transportation, Inventory, Motion, Excess Processing.

Finance. Financial planning is a process that consists of: openly analyzing investment options and funding for the company, projecting the future state of the current decision, deciding on alternatives to be taken, and measuring the subsequent performance of the goals set forth in the financial plan (Braley, Myers, and Marcus, 2001: 82).

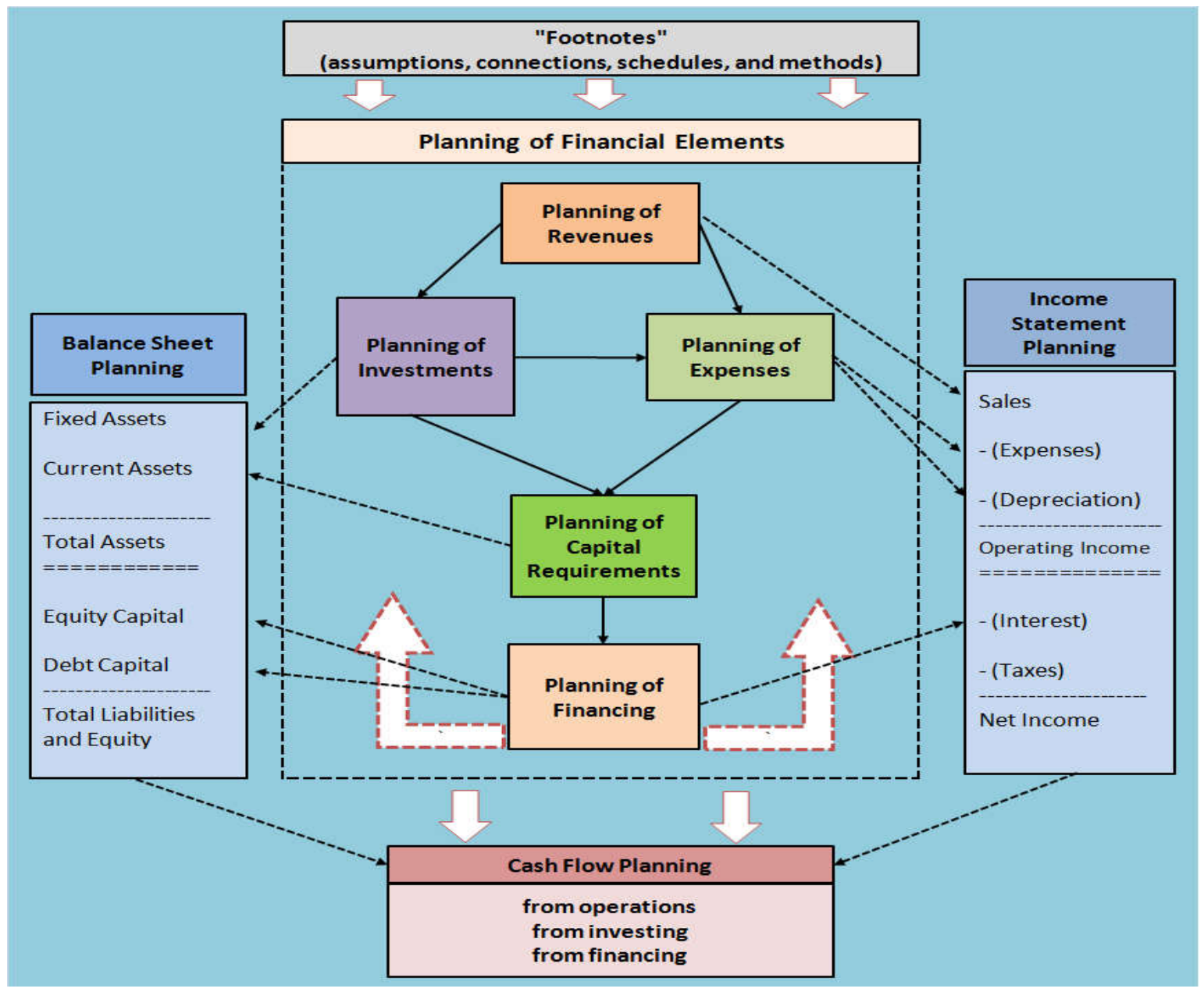

Figure 3 - Conceptual Framework of Financial Planning. Source: Gansel (2005). 
According to Gansel (2005) in his scientific publication "Toward a Framework of Financial Planning in New Venture Creation", he defines financial planning as a systematic process and quantitative forecasting of all relevant cash inflows and cash outs in the utilization of business opportunities to support financial decisions in the planning period the future. The financial planning process is considered being part of a decision-making tool that includes three core components: profit and loss statement planning, balance sheet report planning, and cash flow statement planning. The core component requires five planning elements comprising: revenue planning, cost planning, investment planning, capital planning, and funding planning. Conceptual framework of financial planning (conceptual framework of financial planning).

As a first step in the financial planning process, it is necessary to establish assumptions that are the basis of calculation in revenue planning, cost planning, investment planning, capital planning, funding planning, and pro forma financial statement planning (profit and loss, balance sheet, and cash flow). The assumptions used in the financial planning business peking duck breeding farms in PT Prima Duckindo consisting of assumptions on departments of duck breeding (breeder farm), hatchery department (hatchery), animal husbandry duck breeding department (grower farm), and Poultry Butchery House.

In accordance with SFAS No. 23, revenue is the gross inflows of economic benefits arising from the normal activities of a company during a period when such inflows result in an increase in equity, which is not derived from the investor's contribution. Revenue is income arising from the activities of a company known by different names such as sales, fees, interest, dividends, royalties and rent.

Based on accrual accounting, (in accordance with generally accepted accounting principles), revenue recognition does not have to wait until cash is received. The conceptual framework of accounting has identified two criteria that should be considered in determining when income should be recognized, that is: realized or can be realized, and has been generated or has occurred. Revenue is stated to have been realized if the received asset can be converted into cash immediately. Revenue is deemed to have been generated or has occurred if the company has done what it ought to do to earn the right to that income (Hery, 2016: 68).

The company in determining the policy of revenue recognition (sale and interest income of banks) in accordance with the provisions of PSAK No. 23. Revenue is measured at the fair value of the benefits received or receivables on the sale of goods from the normal activities of the enterprise. Revenue is presented in the statement of income after deducting the value added tax, returns, rebates and discounts. Revenue is recognized when it is probable that the economic benefits will flow to the company and that revenue can be measured reliably. Revenues from the sale of goods are recognized when significant risks and ownership have been transferred to customers. Interest income is recognized on a proportion basis using the effective interest rate method.

Expenses are the uses of goods and services in order to obtain an income (revenue) in a period and these costs into expired for the future (Ishak and Sugiono, 2015: 16). According to Ishak and Sugiono (2015: 19), based on the time charged (timing of charges) and income (revenue), the costs are classified into: 1) the cost of the product (product cost), that all the accumulated production costs occur until the goods are finished (finished goods), where the costs become assets until the time is sold, and the time sold for the production cost will be the burden (cost of good sold); 2) the cost of the period (period cost), all the cost of the period that occurs during a period will be directly expense, including the selling expenses and general administrative expenses. Broadly speaking, load recognition can be divided into three categories, namely direct comparison, systematic and rational allocation, and immediate recognition.

Investment decision is the most important policy of two other policies in financial management, namely funding policy and dividend policy. Capital investment as a major aspect of financial management policy because investment is a form of capital allocation whose realization should produce benefits or profits in the future. On the other hand, future 
investment benefits are overwhelmed by uncertainty, which in the concept of financial management it is called investment risk. As a consequence, investing must go through a careful evaluation process on profit and risk level predictions (Harmono, 2016: 8).

To start this livestock business, there are investment activities that all done at the beginning of the establishment of the company. The initial capital investment value includes all the power required to run the company over a period of 10 years from the time the company establishes. In addition, for the business to run in accordance with the planning required working capital to finance the operational activities from the start the company was founded until the company generates cash from the sale of products.

Capital Management. Working capital is the company's investment in short-term assets, such as, receivables and inventories. Gross working capital is the amount of current assets of the company, while net working capital is the amount of current assets minus current liabilities. The working capital management covers either from the source side of working capital or its use. The main functions of working capital management are 1) adjusting the level of the company's sales activity to changes in seasonal factors, business cycles, or other unpredictable business conditions, and 2) helping the company to achieve the goal of maximizing value (Kamaludin and Indriani, 2012: 115).

In the working capital management, the company uses an approach that prioritizes long-term loans to fund all the needs of the permanent operating assets and some of the needs of seasonal operations. This approach is done to reduce the risk of the company's inability to repay the loan than if the company uses more short-term loans. This working capital management policy will increase shareholder value. Elements that are included in the management of working capital are cash, accounts receivable, accounts payable, inventory, taxes payable, and the various costs money to be paid.

The first component of working capital is cash. It is the most liquid form of assets which can be used immediately to meet the financial obligations of the company. The liquid nature, cash provides the lowest profits. If the company keeps the cash in the bank in the form of a checking account, then the demand deposit service received by the company percentage will be lower than if deposited in a time deposit (which is not at all time cashable). Therefore, the main problem for cash management is to provide adequate cash, not too much so that profits are not reduced too much, but not so little that it will disrupt the company's liquidity (Nidar, 2016: 104).

The company applies a cash adequacy strategy related to working capital based on the following two purposes: (1) working capital requirement for the next one month, the company's cash position must be equal to or exceed the estimated working capital requirement of the company one month ahead; and (2) working capital requirements based on the company's cash conversion cycle will take into account the required working capital needs based on the inventory conversion period, the timing of the collection of accounts receivable, and the repayment of short-term debt.

Cash is managed by using CCC (Cash Conversion Cycle) to determine the effectiveness of cash performance of the company. CCC describes how long the company can collect cash from the company's operating results which will ultimately affect the amount of funds needed to be deposited on current assets. The company's cash should always be in a positive and smooth condition. It means that all existing cash surplus will only be stored in the form of demand deposits and deposits. It is to facilitate the company if at any time it needs funds for operations and investments, assets owned by the company in the form of liquid assets and easily disbursed.

Company needs to conduct an economic analysis of accounts receivable, meant by economic analysis is an analysis that aims to assess whether the benefits of having a larger receivable or smaller than its cost. If it is estimated that the benefits are greater, then the economic ownership of the receivable (or sale of credit), is justified. The analysis is one part of the management of accounts receivable. Another problem is the control of accounts receivable.

Regarding to control of accounts receivable, the company needs to establish its credit policy. This policy then serves as the credit standard. If then in the implementation of credit 
sales and collection of receivables are not in accordance with predetermined standards, then the company needs to make improvements. Activities to ensure that the results are in accordance with the plan is the essence of the control function.

Sales policy with cash and credit system becomes company policy. This certainly gives implications for the emergence of accounts receivable for the company. The terms of payment of receivables set by the company are $2 / 15, \mathrm{n} / 30$. To anticipate the existence of bad debts, the company annually budgets the cost of doubtful accounts for $1 \%$ of total sales.

The high inventory allows the company to meet sudden demand. Nevertheless, high inventory will cause the company need more working capital also. If the company is able to predict precisely the need for raw materials (or finished goods), the company can provide inventory on time according to the required amount. At no time is needed inventory amount can be reduced or even zero. This technique is known as just in time or zero inventory. For financial management, it is necessary to understand the impact of the use of an inventory policy on the financial aspects (Nidar, 2016: 128).

Company divided inventory into three types, namely: (1) Parent stock. Parent stock is stated at cost less accumulated depletion, death, and duck stocks. Costs incurred during the growth period are accumulated and depleted from the commencement of production. Depletion is calculated using the declining balance method based on the estimated productive age of the ducks having produced since the beginning of the production period by taking into account the residual value. Depletion period is 18 months; (2) Livestock in growth. Livestock in growth is a breeder duck. This account represents the cost of day-old ducks (DOD) accumulated with costs incurred during the growth period which includes the cost of feed, medicines, vitamins, and others; (3) Animal Feed. Duck feed consists of concentrate and other ingredients; (4) Meat Inventory. This inventory is cut meat (carcass) that is ready for sale. The company records the inventories of raw materials and finished goods based on FIFO (First In First Out) method. Characteristics of products and raw materials stored in the company are durable and not easily damaged. The company sets raw material inventory for 10 operational days. As for the finished product, the company has a finished product inventory policy within 5 days.

Accounts payable are related to the policies and approval of payment systems applied by the company with other parties such as suppliers. In the first year, it is assumed that supplier of PT.Prima Duckindo will make payment of raw materials with cash system. However, in the second year onwards, it is assumed that the company will gain confidence to be given debt for raw material expenditures with a 30-day pay period.

PT. Prima Duckindo will meet its corporate tax obligations. The tax in question is Corporate Income Tax (PPB). The amount of GDP according to the applicable provisions is $25 \%$. Through Law No. 36 of 2008 , the government implemented a single tax rate policy for MARPs, not the progressive tax rate as set out in Law No. 17 of 2000. This Income Tariff is effective from 2010. In compliance with applicable regulations, if the enterprise incurred a loss, the loss may be brought to the next tax year (carried forward) to reduce taxable income from the subsequent tax year in a row to five years. PT. Prima Duckindo will pay corporate income tax which arises to the state treasury no later than 31 April every year.

It is the selling price of the factory and not including the distribution cost. The selling price is estimated to increase by $6 \%$ every year to adjust the inflation assumption of about $6 \%$ per year.

Cost of goods sold includes the cost of raw materials, material costs, labor costs, depletion costs, and manufacturing costs. In accordance with the company's main strategy, namely differentiation, PT.Prima Duckindo strives to provide the best quality for the creation of duck carcass meat products. Costs of Goods Sold (HPP) per unit product and the proportion of Costs of Goods Sold (HPP) to sales for the period 2018 - 2022 are as follows in Table 1.

The dividend policy determines how much profit to shareholders and how much to replant to the company. The company will take a residual dividend policy where the company will routinely distribute dividend annually with a certain percentage of net income. The nominal amount refers to the percentage target of the dividend payout ratio to be determined 
by the shareholders at the GMS, which will be $20 \%-40 \%$. This policy is done because as a newly established company and focusing on growth, the company requires substantial capital to support the objective, so that the results of operational activities are reused to finance larger operational activities.

Table 1 - Proportion of Cost of Goods Sold in 2018 - 2022

\begin{tabular}{|c|c|c|c|c|c|}
\hline \multirow{2}{*}{ Sales } & \multicolumn{5}{|c|}{ Year Period (Rp) } \\
\cline { 2 - 6 } & 2018 & 2019 & 2020 & 2021 & 2022 \\
\hline $\begin{array}{c}\text { Carcass of Peking } \\
\text { duck }\end{array}$ & 3.381 .183 .000 & 14.190 .684 .300 & 19.576 .428 .300 & 26.237 .763 .337 & 35.997 .172 .575 \\
\hline $\begin{array}{c}\text { DOD of Breeder } \\
\text { Peking Duck }\end{array}$ & - & - & - & 201.096 .000 & 1.160 .212 .200 \\
\hline Total of Sales: & 3.381 .183 .000 & 14.190 .684 .300 & 19.576 .428 .300 & 26.438 .859 .337 & 37.157 .384 .775 \\
\hline $\begin{array}{c}\text { Cost of Goods Sold } \\
\text { (COGS) }\end{array}$ & 2.126 .262 .290 & 8.269 .088 .445 & 11.226 .549 .958 & 15.271 .414 .936 & 21.994 .996 .716 \\
\hline Proportion of COGS & $62.89 \%$ & $58.27 \%$ & $57.35 \%$ & $57.76 \%$ & $59.19 \%$ \\
\hline COGS per unit & 23.912 .08 & 23.573 .71 & 24.613 .09 & 26.173 .87 & 28.242 .83 \\
\hline Total of COGS (Rp) & 2.126 .262 .290 & 8.269 .088 .445 & 11.226 .549 .958 & 15.137 .445 .683 & 21.263 .533 .417 \\
\hline Proportion of COGS & $62.89 \%$ & $58.27 \%$ & $57.35 \%$ & $57.69 \%$ & $59.07 \%$ \\
\hline COGS per unit & - & - & - & 11.751 .69 & 11.739 .10 \\
\hline Total of COGS (Rp) & - & - & - & 133.969 .253 & 731.463 .299 \\
\hline Proportion of COGS & - & - & - & $66.62 \%$ & $63.05 \%$ \\
\hline
\end{tabular}

Funding Planning. According to Harmono (2016: 137), the capital structure is concerned with how capital is allocated in the real investment activities of the company's assets by determining the capital structure between debt and own capital. Usually, related to the project proposal, an investment company and the task of financial management is determining the optimal capital structure to support the company's investment activities.

According to Kamaludin and Indriani (2012: 304), in determining the policy of capital structure, it will involve the choice of trade-off between risk and rate of return. Considerations to be thought are: 1) if using more debt will increase the risk that will be borne by the shareholders, ultimately it will increase the risk of bankruptcy; 2) the use of more debt will also enlarge the the expected rate of return.

Funding needed by PT. Prima Duckindo for the implementation of integrated breeder duck business operation is Rp 5,500,000,000, - for initial establishment of company which consist of investment capital and working capital as required. Funding at the beginning of the establishment of the company's operations comes from the founder and assisted loans to third parties (creditor). Founder consists of 5 people with total funding of $R p$ 2.805.000.000,00 with the issuance of 2,805 shares @ nominal Rp 1,000,000 per share, each founder gets the same proportion of 561 shares. Third party loan of Rp.2.695.000.000,00 derived from a mix of family funding, and other third parties. The capital structure comprises $51 \%$ of the capital deposit from the founders and $49 \%$ is based on third party loans with the assumption of $15 \%$ interest rate per year. Using the long term financing from third parties, the company conservatively uses a more conservative approach in working capital management.

Capital cost is the rate of return for a project in an investment decision to maintain market value and obtain funds (Kamaludin and Indriani, 2012: 287). According to Nidar (2016: 84), the appropriate capital cost for all decisions is the weighted average of all cost components (Weighted Average Cost of Capital or WACC). Not all capital component is taken into account in determining WACC. Accounts payable are not taken into account in the determination of the WACC, because: 1) it cannot be controlled by management, 2) treated as cash flow net working capital in the capital budgeting process.

Notes payable or short-term interest-bearing debt iw included in the calculation of the WACC only if the debt is part of a proficiency level of spending remains firm, not a temporary learning. In general, long-term debt from equity is an element to calculate WACC. Thus, we must calculate 1) the cost of debt, 2) the cost of retained earnings, 3) the cost of the new 
common stock, and 4) the cost of preferred stock. The cost of capital should be calculated on an after tax basis since the after-tax cash flow is the most relevant for investment decisions.

Financial statements are the end products of a series of recording and processing of business transaction data (Hery, 2016: 2). The financial statements are used as a tool to communicate financial data or corporate activities to stakeholders which indicates the condition of a company's financial health or company performance. The main financial statements consist of: (1) Income Statement; 2) Balance Sheet Report; and (3) Statement of Cash Flows.

As a new company that will be established, financial statements can be made based on the data financial assumptions used in business planning. The financial statements presented in the form of proforma financial statements.

Based on proforma's projected income statement, the company can project net profit after tax in 2018 of Rp $537,803,612$ or $15.91 \%$ of total net income; in 2019 the company projected net profit after tax of Rp $3,653,648,491$ or $25.75 \%$ of total revenue; in 2020 the company projected net profit after tax of $\mathrm{Rp} 5,310,490,915$ or $27.13 \%$ of total revenues, in 2021 the company projects net profit after tax of $\mathrm{Rp} 7,200,655,537$ or $27.24 \%$ of total revenues; and by 2022 the company projects net profit after tax of Rp 9,818,906,389 or $26.43 \%$ of total revenue.

In 2018, the company has not paid dividends to shareholders, the cash flows generated from net income are used for working capital financing. In 2019, the company distributes dividend of $20 \%$ of net profit and the rest is used for next year's working capital financing. In 2020, the company increases the dividend distribution to shareholders by $30 \%$ from net profit and the rest is used for next year's working capital financing. In 2021, the company increases the dividend payout of shareholders by $35 \%$ of net profit and the rest is used for working capital financing of the following year. In 2022, the company continues to increase the distribution of dividends to shareholders by $40 \%$ of net profit and the rest is used for next year's working capital financing.

Balance sheet is a systematic report on the asset position, obligation, and equity of the company at certain date. The purpose of the balance sheet report is to describe the company's financial position.

The statements of cash flows are reports that describe the cash inflows and cash outflows in detail from each activity, starting from operating activities, investment activities, to financing activities for a certain period of time. The cash flow statement shows the amount of cash increase or decrease in cash owned by the company up to the end of the period.

The financial ratio is the ratio calculation by using financial statements that serve as a measuring tool in assessing the financial condition and performance of the company (Hery, 2016: 18). The financial ratio presents the figures derived from the comparison between one financial report post and another post with relevant and significant relations. Comparisons can be made between one post and another in a financial statement or between posts that exist between financial statements.

Financial ratio analysis is an analysis performed by linking various estimates that exist in the financial statements in the form of financial ratios. Financial ratio analysis can reveal important relationships between financial statement estimates and can be used to evaluate the company's financial condition and performance. The types of financial ratios often used to assess the company's financial condition and performance are (1) Liquidity Ratios, (2) Sovability Ratios, (3) Activity Ratios, and (4) Profitability Ratios.

The most important investment valuation method used in measuring feasibility investments in PT Prima Duckindo's livestock business is Payback Period. Payback period is the most commonly used method of business to measure the length of reinvested investment funds. Therefore the result of the calculation is expressed in units of time (ie year or month). The faster the investment return period, the less investment risk, and the investment project is feasible to run. Conversely, the longer the return the greater the investment risk, and the investment project is less feasible or unfit to run.

Well-planned financial planning and in harmony with the established strategy will be able to direct the company in achieving its goals effectively and efficiently. 
Table 2 - Financial Planning for Investors (Package 1)

\begin{tabular}{|c|c|c|c|c|c|c|}
\hline \multirow{2}{*}{\multicolumn{2}{|c|}{$n / n$}} & \multicolumn{5}{|c|}{$\begin{array}{l}\text { FINANCIAL PLANNING FOR INVESTORS } \\
\text { (Million Rupiah) }\end{array}$} \\
\hline & & Year 1 & Year 2 & Year 3 & Year 4 & Year 5 \\
\hline 1). Investment Package & & 5.500 & - & - & - & - \\
\hline 2). Financing Structure: & & & & & & \\
\hline Founder Capital & $20 \%$ & 1.100 & & & & \\
\hline Investor Capital & $80 \%$ & 4.400 & & & & \\
\hline 3). Payback Period: & $\begin{array}{l}2 \text { Years } \\
4 \text { Months }\end{array}$ & & & & & \\
\hline 4). Net Profit Projection: & & & & & & \\
\hline Net Sales & & 3.381 & 14.190 & 19.576 & 26.438 & 37.157 \\
\hline COGS & & $(2.126)$ & $(8.269)$ & $(11.226)$ & $(15.271)$ & $(21.995)$ \\
\hline Gross Profit & & 1.255 & 5.921 & 8.350 & 11.167 & 15.162 \\
\hline $\begin{array}{ll}- & \text { Expense of Sales, Administration, and Other } \\
\text { Operational Expense/Revenue }\end{array}$ & & (167) & (763) & $(1.067)$ & $(1.462)$ & $(2.086)$ \\
\hline - $\quad$ EBIT & & 1.088 & 5.158 & 7.283 & 9.705 & 13.076 \\
\hline - $\quad$ Revenue and Financial Expense & & (371) & (287) & (203) & (105) & 15 \\
\hline$-\quad$ EBT & & 717 & 4.871 & 7.080 & 9.600 & 13.091 \\
\hline Income tax expense & & $(179)$ & $(1.217)$ & $(1770)$ & $(2.399)$ & $(3.272)$ \\
\hline EAT & & 538 & 3.654 & 5.310 & 7.201 & 9.819 \\
\hline Profit Sharing for Investors (50\%) & & 269 & 1.827 & 2.655 & 3.601 & 4.910 \\
\hline
\end{tabular}

Table 3 - Financial Planning for Investors (Package 2)

\begin{tabular}{|c|c|c|c|c|c|c|}
\hline \multirow{2}{*}{\multicolumn{2}{|c|}{$n / n$}} & \multicolumn{5}{|c|}{$\begin{array}{c}\text { FINANCIAL PLANNING FOR INVESTORS (Million } \\
\text { Rupiah) }\end{array}$} \\
\hline & & Year 1 & Year 2 & Year 3 & Year 4 & Year 5 \\
\hline 1). Investment Package & & 11.000 & - & - & - & - \\
\hline \multicolumn{7}{|l|}{ 2). Financing Structure: } \\
\hline Founder Capital & $15 \%$ & 1.650 & & & & \\
\hline Investor Capital & $85 \%$ & 9.350 & & & & \\
\hline 3). Payback Period: & $\begin{array}{l}2 \text { Years } \\
4 \text { Months }\end{array}$ & & & & & \\
\hline \multicolumn{7}{|l|}{ 4). Net Profit Projection: } \\
\hline - $\quad$ Net Sales & & 6.762 & 28.380 & 39.152 & 52.876 & 74.314 \\
\hline COGS & & $(4.252)$ & $(16.538)$ & $\overline{(22.452)}$ & $(30.542)$ & $(43.990)$ \\
\hline Gross Profit & & 2.510 & 11.842 & 16.700 & 22.334 & 30.324 \\
\hline $\begin{array}{ll}- & \text { Expense of Sales, Administration, and Other } \\
\text { Operational Expense/Revenue }\end{array}$ & & (334) & $(1.526)$ & $(2.134)$ & $(2.924)$ & $(4.172)$ \\
\hline$-\quad$ EBIT & & 2.176 & 10.316 & 14.566 & 19.410 & 26.152 \\
\hline $\begin{array}{ll}- & \text { Revenue and Financial Expense }\end{array}$ & & $(742)$ & (574) & $(406)$ & (210) & 30 \\
\hline - $\quad$ EBT & & 1.434 & 9.742 & 14.566 & 19.200 & 26.182 \\
\hline Income tax expense & & $(358)$ & $(2.434)$ & $(3.540)$ & $(4.798)$ & $(6.544)$ \\
\hline EAT & & 1.076 & 7.308 & 10.620 & 14.402 & 19.638 \\
\hline Profit Sharing for Investors (50\%) & & 592 & 4.019 & 2.655 & 7.921 & 10.801 \\
\hline
\end{tabular}

Table 4 - Financial Planning for Investors (Package 3)

\begin{tabular}{|c|c|c|c|c|c|c|}
\hline \multirow{2}{*}{\multicolumn{2}{|c|}{$n / n$}} & \multicolumn{5}{|c|}{$\begin{array}{l}\text { FINANCIAL PLANNING FOR INVESTORS (Million } \\
\text { Rupiah) }\end{array}$} \\
\hline & & Year 1 & Year 2 & Year 3 & Year 4 & Year 5 \\
\hline 1). Investment Package & & 16.500 & - & - & - & - \\
\hline 2). Financing Structure: & & & & & & \\
\hline - $\quad$ Founder Capital & $10 \%$ & 1.650 & & & & \\
\hline Investor Capital & $80 \%$ & 14.850 & & & & \\
\hline 3). Payback Period: & $\begin{array}{l}2 \text { Years } \\
4 \text { Months }\end{array}$ & & & & & \\
\hline 4). Net Profit Projection: & & & & & & \\
\hline Net Sales & & 10.143 & 42.570 & 58.728 & 79.314 & 111.471 \\
\hline COGS & & $(6.378)$ & $(24.807)$ & $(33.678)$ & $(45.813)$ & $(65.985)$ \\
\hline Gross Profit & & 3.765 & 17.763 & 25.050 & 33.501 & 45.486 \\
\hline $\begin{array}{ll}- & \text { Expense of Sales, Administration, and Other } \\
\text { Operational Expense/Revenue }\end{array}$ & & (501) & (2.289) & (3.201) & $(4.386)$ & $(6.258)$ \\
\hline EBIT & & 3.264 & 15.474 & 21.849 & 29.115 & 39.228 \\
\hline Revenue and Financial Expense & & $(1.113)$ & (861) & $(609)$ & (315) & 45 \\
\hline EBT & & 2.151 & 14.613 & 21.240 & 28.800 & 39.273 \\
\hline Income tax expense & & $(537)$ & (3.651) & $(5.310)$ & $(7.197)$ & $(9.816)$ \\
\hline - $\quad$ EAT & & 1.614 & 10.962 & 15.930 & 21.603 & 29.547 \\
\hline Profit Sharing for Investors ( $50 \%)$ & & 968 & 6.577 & 9.558 & 12.962 & 17.674 \\
\hline
\end{tabular}


The company has made a financial planning decision or policy to run an integrated peking breeder duck business with eco-green model project with funding sourced from founder capital and third party loans. From initial investment capital of Rp 5.5 billion, net profit can be achieved above $25 \%$ annually and the return on investment (payback period) can be achieved within 2 years and 4 months.

Duck meat market prospects are large enough especially for the needs of the stalls and restaurants, we are optimistic that large-scale breeding business of breeder duck is very feasible to run with funding from investors.

\section{CONCLUSION AND SUGGESTIONS}

Duck breeding business managed by PT Prima Duckindo with Eco-Green concept becomes a profitable business and becomes pilot farming business with dry stable, economical, and environmentally friendly method. Many advantages are obtained with the concept of farms that work on the company such as the production of farm produce Peking duck meat with taste quality, nutritional content are met and it is low cholesterol. Thus, with the establishment of duck breeding business conducted PT Prima Duckindo, it positively gives impact on the populist economy and also increases the supply of meat according to the needs of the people of Indonesia who are currently still experiencing a deficit of meat supply.

With various analyzes conducted by the company, in the development of duck breeding business run by PT Prima Duckindo, it needs reliable operational management. The operational framework of PT Prima Duckindo in conducting the Pre-Operational stage is the result of QSPM analysis which is the operational objective of the company. Beginning from planning activity, it implements enterprise project management system with its Gantt Chart. PT Prima Duckindo is an integrated farm starting from breeding, hatching, farming or growing, cutting ducks to become carcasses. Therefore, to achieve the above objectives, then it needs mapping the operational strategy comprehensively by always doing continuous improvement (kaizen) because in the current era, to be good alone is not enough but strive to be superior (market leader) is needed by beginning by cost leader.

Business plan designed by PT Prima Duckindo can be used as an example in other poultry farm business or duck farm that still used traditional concept. As for management in developing peking duck breeding companies, it needs innovations and develops more effective and more efficient technology that can produce better duck breeding outcome.

The business plan designed by PT Prima Duckindo can also be used as reference material for Graduate students as the final project of business plan and also material of study of research material in building a business. For business plan government designed PT Prima Duckindo, it can be developed as a business that can improve people's welfare; this business plan can be a reference for the community or entrepreneurs who are willing to build duck breeding business.

\section{REFERENCES}

1. Brealey, R.A. (2001). Fundamentals of corporate finance. New York: McGraw-HIII/Irwin.

2. Gansel, B. (2005). Toward a framework of financial planning in new venture creation. Research Paper, Otto-von-Guericke-Universität Magdeburg, Germany.

3. Harmono. (2016). Manajemen Keuangan. Berbasis Balanced Scorecard Pendekatan Teori, Kasus dan Riset Bisnis. Bumi Aksara. Jakarta. Cetakan kelima.

4. Hery. (2016). Analisis Kinerja Manajemen. "The Best Financial Analysis. Menialai Kinerja Manajemen Berdasarkan Rasio Keuangan". Grasindo. Jakarta.

5. Hery. (2016). Finacial Ratio for Business."Anallisis Keuangan Untuk Menilai Kondisi Finansial dan Kinerja Perusahaan". Grasindo. Jakarta.

6. Hery. (2016). Praktis Menyusun Laporan Keuangan. Grasindo. Jakarta. Cetakan ke-2.

7. Ishak (2015). Akuntansi, Informasi dalam Pengambilan Keputusan. PT.Grasindo.

8. Kamaludin (2012). Manajemen Keuangan. Edisi Revisi. Bandung: CV. Mandar Maju.

9. Nidar, S. R. (2016). Manajemen Keuangan Perusahaan Modern. Pustaka Reka Cipta. 